\section{Snarveier i livets utvikling}

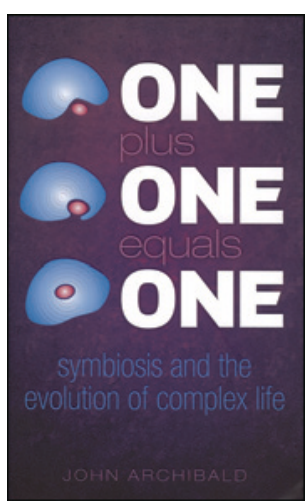

John Archibald

One plus one equals one

Symbiosis and the evolution of complex life. 205 s, ill. Oxford: Oxford University Press, 2014. Pris GBP 17

ISBN 978-0-19-966059-9

Etter Carl von Linnés tid har det skjedd store forandringer i den systematiske oppstillingen av alle livsformene. Systemer basert på artenes utseende må nødvendigvis bli misvisende, når de fleste arter er usynlige uten mikroskop, som Linné ikke hadde.

Cellebiologi med DNA-sekvensering har ofte ført til overraskende funn om genetisk slektskap. Mennesket har nå fått en beskjeden plass på en liten gren, animalia, som har felles utspring med fungi. I stedet for to kongeriker, planter og dyr, er det nå tre domener: eubakterier, erkebakterier (archae) og eukaryoter. Hvis de to første domener slås sammen, får vi to superdomener: prokaryoter, som har celler uten cellekjerner, og eukaryoter, som har celler med cellekjerner. Begge domener har mange kongeriker. De mest tallrike organismene, både i arter og antall, er prokaryotene. De har da også hatt mest tid på seg. Bakterier og archae finnes overalt. De eldste er kanskje de termofile, som trives best ved høy temperatur, lav pH og lite oksygen. Antallet ukjente arter er meget stort. Eukaryoter er større og mer komplekse organismer enn bakterier. I tillegg til cellekjerner har de også organeller som cytoskjelett, endoplasmatisk retikulum og mitokondrier eller kloroplaster. De har evne til den meget presise celledelingsmekanismen som kalles mitose, og de kan danne flercellede skapninger. Det er de eukaryote cellene som har gjort jorden grønn, og som har skapt fisk i havet, dyr på land og fugler i luften.

Boken med den underlige tittelen som omtales her, handler vesentlig om hvordan de komplekse eukaryotene er blitt dannet fra de små og relativt enklere prokaryotene. Det er nå alminnelig enighet om at et viktig trinn i denne utviklingen er det fenomenet som kalles endosymbiose, selv om det stadig gjenstår å få en del detaljer på plass. Man regner med at noen ukjente protoeukaryoter uten cellevegg, men med en tynn ytre membran kan ha foldet seg rundt en bakterie. Cellembranen med bakterie blir snørt av, og bakterien befinner seg plutselig inne i den store vertscellen, uten å bli spist opp. Den oppslukte «symbiont» har antakelig vært av typen alfa-proteobakterier med mitokondrier. Den er nå blitt en «endo- symbiont» som utveksler gener med vertens cellekjerne. Det utvikler seg et proteinimportsystem, og bakterien blir til en organelle. Denne organellen er oftest en mitokondrie. Alternativt kan en frittflytende mitokondrie bli tatt opp separat.

Endosymbiose forklarer hvorfor man finner eget mitokondrieDNA, som er i slekt med med bakterie-DNA, i eukaryote celler. Endosymbiose forklarer også hvordan fotosyntese oppsto i eukaryoter. Symbionten var nå en cyanobakterie med kloroplast, og resultatet ble en plantecelle. Også her skjer det transport av DNA fra endosymbiontens genom til vertens kjernegenom. Prosessen kalles «endosymbiotic gene transfer» (EGT). En slik horisontal utveksling av gener kan spare tid i forhold til vertikal utvikling basert på tilfeldige mutasjoner. Fordelen for den eukaryote cellen er bl.a. en økning i energiomsetning og proteinsyntese. Symbionten unngår å bli spist. Endosymbiose er antakelig en vanlig prosess.

John Archibald er molekylærbiolog ved Dalhousie University i Canada, med særlig interesse for utviklingsbiologi på cellulært nivå. I denne boken viser han stor entusiasme kombinert med evne til å ta leseren med på en reise gjennom temaet symbiose hos mikroorganismer. Boken vinner på at forfatteren går tilbake i historien og forteller om de forskere som har arbeidet på dette feltet. Det var lenge stor uenighet. Temperaturen på seminarene må av og til ha vært ganske høy. Det tok tid å nå frem til en felles oppfatning om at endosymbiose ikke bare er en realitet, men av stor betydning for utviklingen av livet på jorden. Boken er ikke spesielt stor. Den har gode illustrasjoner og forklarer nye faguttrykk. Litteraturliste og indeks er overkommelig for dem som vil vite mer om dette fascinerende temaet. Men for de fleste vil nok John Archibalds bok være tilstrekkelig.

\section{Anton Hauge}

Professor emeritus i fysiologi, Universitetet i Oslo 